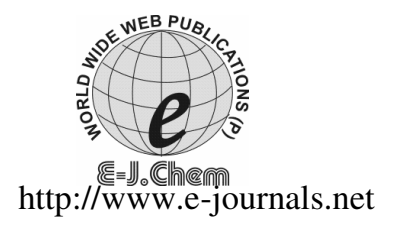

ISSN: 0973-4945; CODEN ECJHAO E-Journal of Chemistry 2010, 7(4), 1278-1283

\title{
Physicochemical and Heavy Metals Assessments of Leachates from Aperin Abandoned Dumpsite in Ibadan City, Nigeria
}

\author{
G.O.ADEWUYI* and M.A.OPASINA \\ *Department of Chemistry, University of Ibadan, Ibadan, Nigeria. \\ Department of Chemistry, \\ Emmanuel Alayande College of Education Lanlante, Nigeria. \\ adewuyio@yahoo.co.uk
}

Received 12 January 2010; Accepted 7 March 2010

\begin{abstract}
Leachates from Aperin dumpsite and control site in Ibadan city, were analysed for physicochemical properties and heavy metals levels. These parameters were compared with control samples and established international standards (FEPA) and (WHO). The dumpsite leachates contained very high concentration of TDS $(2436 \pm 1035 \mathrm{mg} / \mathrm{L})$ and significant concentrations of COD $(395 \pm 135 \mathrm{mg} / \mathrm{L})$, BOD $(170 \pm 33 \mathrm{mg} / \mathrm{L})$, Alkalinity $(1157 \pm 995 \mathrm{mg} / \mathrm{L}), \mathrm{Cl}^{-}$ $(943 \pm 175 \mathrm{mg} / \mathrm{L}), \quad \mathrm{NO}_{3}^{-} \quad(0.66 \pm 0.22 \quad \mathrm{mg} / \mathrm{L}) \quad \mathrm{PO}_{4}^{-}(1.98 \pm 0.89 \quad \mathrm{mg} / \mathrm{L})$. High concentrations of iron, manganese, copper, zinc, nickel, cadmium and lead were also observed. All, the parameters were above control and exceeded FEPA and WHO guidelines. The study revealed that this dumpsite is a major polluting source in the surrounding environment. This underlines the need for appropriate government agency Oyo State, Nigeria to initiate an active remediation process such as phytoremediation in combination with physicochemical methods to recover the dumpsite from contaminants and reduce the level of pollution in the surrounding environment.
\end{abstract}

Keywords: Leachates, Dumpsite, Physicochemical, Remediation, Phytoremediation,

\section{Introduction}

In developing countries, there is an increasing awareness to minimize the levels of pollutants discharged into the environment. The United Nation Environmental Programme (UNEP) is drawing the attention of nations towards consequences of pollution. The root cause of environmental pollution has been man's tendency to dilute and disperse wastes rather than to remove them at the source. With ever increasing population, urbanization and industrialization, the environment is considerably polluted even in the developing countries. Many dumpsites in urban areas have been converted into heavily polluted sites. In most cities 
in Nigeria, co-disposal of industrial, municipal, domestic and medical wastes in open and unsecured dumpsites and non sanitary landfills is a common practice. Wastes are haphazardly deposited as a result of which adjoining lands get enriched in salts and trace metals; thereby posing threat to the environment. Dumped soil wastes are exposed to precipitation from rain, melted snow or the waste itself. As the liquid flows through the dumpsite, salts, organic and inorganic compounds are transported in the leachates. Leachates can move as surface water or percolate through the underlying strata and have very high polluting potentials ${ }^{1-3}$. Chemicals like phthalates, polyaromatic hydrocarbons and other organic micropollutants often found in leachates are assimilated by aquatic species, plants and passed through food chain and bioaccumulate in human on long term exposure ${ }^{4}$. The realization of the polluting effects of dumpsite leachates on the environment has promoted a number of studies ${ }^{5-10}$. These include studies on domestic wastes, leachates quality, as well as underground water quality ${ }^{11}$. Many inorganic anions and cations characterized as toxic in drinking water have being identified in leachates. In addition, micro-organisms, some of which are opportunistic pathogens, have been isolated and identified ${ }^{12}$. Exposure to multiple chemical combination in occupational exposed populations and those residing near dumpsites has led to series of human health disorders ${ }^{13}$, these include organic dysfunction, reproductive, neurobehavioral and genetic disorders.

Ibadan, the largest and one of the most populous cities in Nigeria is experiencing problems of municipal waste management, principally as a result of unplanned development, rural urban migration and natural increase within the city ${ }^{14}$. Yet, this remarkable growth rate has not been matched by improvement in the quality of the urban environment. Instead, these demographic expansion, increased industrialization and commercial activities have caused an astronomical increase in the volume and diversity of solid wastes generated in the city. Aperin municipal dumpsite received wastes from various sources including, domestic, industrial, medical and agricultural over 35 years. It was an unsecured dumpsite and leachates from this site had been implicated in environmental pollution ${ }^{9}$. Fearing further contamination of the environment a pronouncement was made in 2002 by the State Health and Environmental authorities that the dumpsite be shut down to public in order to allow the soil and surrounding environment to recover from previous waste contamination. Very few studies have been conducted to characterize leachates from shut dumpsites in the state. The objective of this study therefore, was to determine the physico chemical status of leachates from the Aperin dumpsite with a view to estimating its pollution effects and to establish the recovery of the dumpsite during this period of inactivity.

\section{Experimental}

Samples were collected randomly at identified locations from the dumpsite and from the control site. The samples were collected in November 2007 during dry season. The dry weather samples were taken when no precipitation had occurred. Collection of soil samples was done using a core sampler at depth of $15 \mathrm{~cm}$ from an area of $15 \mathrm{~cm}$ diameter.

\section{Laboratory studies}

Toxicity characteristic leaching procedure (TCLP) ${ }^{15}$ was used to obtain leachates from soil collected from the dumpsite and control site. Using this procedure, $2.5 \mathrm{~g}$ each of air dried soil samples sieved to about $2 \mathrm{~mm}$ was weighed into a wide mouthed $100 \mathrm{~mL}$ polyethylene jar after which $50 \mathrm{~mL} 0.1 \mathrm{M}$ Sodium acetate buffer was added and mixture agitated on a shaker for $18 \mathrm{~h}$ at $30 \mathrm{rpm}$. The mixture was separated using Whatman Filtered Paper and the resulting filtrates stored at $4{ }^{0} \mathrm{C}$. 


\begin{abstract}
Analysis
Analysis of heavy metals was carried out using BUCK SCIENTIFIC 205 VGP Atomic absorption spectrophotometer after wet digestion with a mixture of $\mathrm{HCl}$ and $\mathrm{HNO}_{3}$. The $\mathrm{pH}$ was determined using glass electrode method with a standard calibrated $\mathrm{pH}$ meter. Electrical Conductivity (EC) was determined from the filtrates obtained from the suspension for $\mathrm{pH}$ analysis using conductivity meter. All the other parameters, Total Dissolved Solids (TDS), Chemical Oxygen Demand (COD), Biochemical Oxygen Demand (BOD), Alkalinity, were determined according to standard procedure ${ }^{16}$. Nitrate was determined by phenoldisulphonic acid method ${ }^{17}$. Phosphate was analysed colorimetrically as molybdophosphoric acid while chloride was determined using volhard method $^{18}$.
\end{abstract}

\title{
Results and Discussion
}

The characteristics of the leachates from the dumpsite and control site are shown in Table 1. The mean $\mathrm{pH}$ for dumpsite leachates is $8.80 \pm 0.48$. This value is higher than control of $6.80 \pm 0.37$ and exceeds Federal Environmental Protection Agency (FEPA) ${ }^{19}$ and World Health Organization (WHO) ${ }^{20}$ regulatory standards of 7.00 respectively. The significance of this $\mathrm{pH}$ imbalance is that it can inhibit or completely wipe out all biological processes that may be necessary for the natural treatment of the abandoned site thereby resulting in incomplete natural treatment and consequent pollution of the surrounding environment. Also, from the $\mathrm{pH}$ value it could be inferred that complex varieties of inorganic soluble substances are still components of the dumpsite and are still active these components are easily leached resulting in the alkaline condition of the leachates. This observation is typical of samples from aged wastes experiencing improper treatment condition. Treatment of waste water resulting from such dumpsite demands high coagulant dosage to ensure sweep coagulation of pollutants if chemical treatment is desirable ${ }^{11}$. The mean leachates conductivity and total dissolved solids are $2155 \pm 1447 \mu \mathrm{s} / \mathrm{cm}$ and $2436 \pm 1035 \mathrm{mg} / \mathrm{L}$. These values were higher than the control values and exceeded FEPA and WHO guidelines. These observations revealed that the leachates contain high proportion of pollutants the significance is that considerable amount of dissolved inorganic materials are present in the dumpsite; such materials can provide adsorptive sites for certain chemicals and biological agents. This process may eventually foster pollution of surrounding soils, vegetation and underground water within the area of the dumpsite. Such similar trend was observed previously ${ }^{11}$.

Table 1. Physico chemical characteristics of leachates from Aperin dumpsite and control site

\begin{tabular}{lccc}
\hline \multicolumn{1}{c}{ Parameters } & Dumpsite value & Control site value & FEPA\& WHO Standards \\
\hline Conductivity, $\mu \mathrm{s} / \mathrm{cm}$ & $8.80 \pm 0.48$ & $6.80 \pm 0.37$ & $6-7$ \\
Total Dissolved & $2155 \pm 1447$ & $170 \pm 55$ & - \\
Solid (TDS), $\mathrm{mg} / \mathrm{L}$ & $2436 \pm 1035$ & $10.4 \pm 1.3$ & 2000 \\
Alkalinity, $\mathrm{mg} / \mathrm{L}$ & $1157 \pm 995$ & $210 \pm 35$ & - \\
Chloride, $\mathrm{mg} / \mathrm{L}$ & $943 \pm 175$ & $65.9 \pm 8.2$ & 600 \\
Nitrate, $\mathrm{mg} / \mathrm{L}$ & $0.66 \pm 0.22$ & $0.32 \pm 0.15$ & 20 \\
Phosphate, $\mathrm{mg} / \mathrm{L}$ & $1.98 \pm 0.89$ & $0.55 \pm 0.10$ & 5 \\
Chemical Oxygen & $395 \pm 35$ & $90.7 \pm 20.0$ & - \\
Demand (COD), mg/L & & & 50 \\
Biochemical Oxygen & $170 \pm 33$ & $70.6 \pm 25.1$ & 5 \\
Demand (BOD), mg/L & & &
\end{tabular}


The alkalinity of the leachates is considerably higher than the control value and also exceeded FEPA and WHO standards. The high alkalinity value is attributed to the agedness of the dumpsite and is correlated with its high $\mathrm{pH}$ value. The levels of chloride determined for the leachates is significantly higher than the control value and far exceeded FEPA and WHO standards. Though chloride does not react chemically with species in water and harmless at relatively low concentration, the higher level observed for the dumpsite leachates is an indication of excess salinity and mineral pollution being active in the dumpsite. The mean values for nitrate is $0.66 \pm 0.22 \mathrm{mg} / \mathrm{L}$ and phosphate is $1.98 \pm 0.89 \mathrm{mg} / \mathrm{L}$ in the dumpsite leachates these values are lower than the control values and also below the FEPA and WHO standard limits. The source of nitrate in the dumpsite leachates could be attributed to plant decomposition process going on in the dumpsite and partly to dumping of human excreta on the dumpsite, which is a common practice in the neighborhoods.

Upon introduction of water, nitrogen undergoes various transformations; which include nitrification. The predominant product of nitrification is nitrate because it is a stable ionic specie. The major source of phosphate could be from detergents garbages and residues from some inorganic fertilizers that have been dumped as agricultural waste on the dumpsite.

The higher concentration of COD and BOD observed for the dumpsite leachates showed that the dumpsite is particularly high in organic contaminants. The dumpsite contains actively decomposing wastes which include pollutants that are soluble in water. Any surface water ingress into the dumpsite will promote solublization of these pollutants which can accumulate and on the long run contaminate surrounding soil and underground water. Aluko et al. ${ }^{11}$ reported similar trend for leachates from municipal solid waste studied in Ibadan, Nigeria. Generally, BOD and COD are inversely proportional to DO and might change depending on the nature of the system being investigated. It could therefore be inferred that the dumpsite cannot support desire aerobic organisms. Leachates that emanates from the dumpsite, may upset water ecosystem if eventually, it emptied into a receiving stream. This development can lead to proliferation of anaerobic biota, that eventually produces anaerobic condition in the nearby stream.

The mean values of heavy metal in dumpsite leachate are shown jn Table 2 . The mean concentration $(\mathrm{mg} / \mathrm{L})$ are $76.63 \pm 22.02(\mathrm{Fe}), 12.55 \pm 3.45(\mathrm{Mn}), 0.80 \pm 0.03(\mathrm{Cu})$, $2.78 \pm 1.05(\mathrm{Zn}), 0,60 \pm 0.03(\mathrm{Ni}), 0.27 \pm 0.14(\mathrm{Cd})$ and $1.52 \pm 0.83(\mathrm{~Pb})$ exceeding the control values. However, the concentrations of $\mathrm{Cd}$ and $\mathrm{Ni}$ were below the permissible limit of $1.0 \mathrm{mg} / \mathrm{L}$ for waste disposal at surface water and the level of $\mathrm{Mn}$ in the leachate is $12.6 \pm 3.5 \mathrm{mg} / \mathrm{L}$ which is much higher than the allowable limit of $5.0 \mathrm{mg} / \mathrm{L}$ set by FEPA and WHO. This observation suggests high possibility of heavy metal accumulation in the dumpsite. In this regard the dumpsite represents a significant source of heavy metal contamination of soils, vegetation and underground water in the surrounding environment. Also it could be inferred that the higher levels of $\mathrm{Fe}, \mathrm{Mn}$ and $\mathrm{Zn}$ recorded for the dumpsite leachates may be responsible for the unacceptable colour of the leachates

Table 2. The content of heavy metals $(\mathrm{mg} / \mathrm{L})$ in stimulated leachate and control samples

\begin{tabular}{cccc}
\hline Heavy metals & Stimulated leachates values & Control values FEPA \& & WHO Standards \\
\hline $\mathrm{Fe}$ & $76.6 \pm 22.0$ & $15.5 \pm 2.7$ & 20.00 \\
$\mathrm{Mn}$ & $12.6 \pm 3.5$ & $2.75 \pm 1.02$ & $<5.0$ \\
$\mathrm{Cu}$ & $0.80 \pm 0.03$ & $0.002 \pm 0.001$ & $<0.2$ \\
$\mathrm{Zn}$ & $2.78 \pm 1.05$ & $0.03 \pm 0.01$ & $<1$ \\
$\mathrm{Ni}$ & $0.60 \pm 0.30$ & $0.02 \pm 0.01$ & $<1$ \\
$\mathrm{Cd}$ & $0.27 \pm 0.14$ & $\mathrm{ND}$ & $<1$ \\
$\mathrm{~Pb}$ & $1.52 \pm 0.83$ & $0.01 \pm 0.01$ & $<1$ \\
\hline
\end{tabular}


Ibadan, have urban migration problems and resource limitation. The development of residential areas near the dumpsite and indiscriminate dumping of Municipal wastes are still observed at this study site despite government closure of the site since 2002 revealed that human activities is still taking place at the dumpsite, since there is a strong relationship between human activities and pollution of the environment ${ }^{21}$. For instance, the dumping of animal droppings is still being practice, because most people living near the dumpsite have converted the site to vegetable garden because of the dumping of animal droppings which js a common practice at the site. Animal droppings are useful agricultural by-products as fertilizer supplements with very high potential for environmental pollution ${ }^{22}$.

\section{Conclusion}

The absence of proper management system and lack of adequate capacity for final deposition of solid waste has been a serious problem in urban areas. Developing countries like Nigeria have not been able to adequately address these problems due to high cost involved. This seems to be one of the reasons why contaminated dumpsites are often shut down for natural recovery of the site. Though there is a scarcity of data on physicochemical status of shut down dumpsites specifically in Oyo state, Nigeria. The data recorded in this study support the assertion that most shut down dumpsites in heavily urbanized society may have been contaminated significantly due to on going human activities. This underlines the need for appropriate authority to further monitor shut down dumpsites alongside remediation process that may be initiated.

\section{Acknowledgements}

The assistance received from Mrs. Ronke Abdulwaheed, Mrs. Fadeke Opeseitan and Pastor Dipo Ayodele during collection and analysis of samples is acknowledged. Also, the authors wish to thank the Department of Chemistry, University of Ibadan, Ibadan. Nigeria for provision of some materials and reagents used in the study.

\section{References}

1. Bartram J M and Balance R, Water Quality Monitoring, T J Press Padstow, Cornwal, England, 1996.

2. Minoslaw R and Vlandinor N B, Practical Environmental Analysis Baston Ltd. Bodmin UK, 1999.

3. Finnecy E E, The case for co-disposal of hazardous waste with municipal Waste In: Hazardous Waste Detection, Control, Treatment, Elsevier Scientufic Publishing Company, Amsterdam, Netherlands 1988, 119.

4. $\quad$ Sang N and Li G, Mutat Res., 2004, 560, 159-165.

5. Cameron R D and Koch F A, J WPCF, 1980, 52(4), 761-769.

6. Loizidou M and Kapentanios E G, The Science of the Total Environment, 1993, 128, 69-81.

7. Aluko O O Sridhar M K C and Oluwande P A Treatment of leachates from Municipal Solid Wastes using Constructed Wetlands: A Nigerian Experience. International Conference on Constructed Wetlands for wastewater Treatment in Tropical and SubTropical Regions, India, 2000, 30.

8. Christensen T H, Kjeidsen P, Bjerg P L, Jensen D L, Christensen J B, Baun A, Albrechtsen H and Heron G, Appl Geochem., 2001, 16(7-8), 659-718.

9. Ikem A, Osibanjo O, Sridhar M K C and Sobande A, Water Air Soil Pollut., 2002, 140, 307-333.

10. Harrison R M and de mora S J, Introduction Chemistry for Environmental Sciences, Cambridge University Press, Britian, 1996. 
11. Aluko O O, Sridhar M K C and Oluwande P A, Nigeria J Environ Health Res., 2002, 2(1), 32-37.

12. Cheung K C, Chu L M and Wong M H, Water Air Soil Pollut., 1993, 69, 337-349.

13. Palmer S R, Dunstan F D J, Fielder H, Fone D L, Higgs G and Senior M L, Environ Health Perspective, 2005, 113, 1362-1365.

14. Akinbiyi R, Africa Health, 1992, 5(1), 26.

15. United State Environmental Protection Agency, Toxicity Characteristic leaching Procedure, Method 1311, SW 846, 1992.

16. APHA, American Water Works Association and Water Pollution Control Federation, Standard Methods for Water and Waste Water, $15^{\text {th }}$ Ed. American Public Association, New York. USA, 1981.

17. Taras J M, J Anal Chem., 1950, 22(8),1020-1022.

18. Jonnalagadda S B, Mathuthu A S, Odipo R W and Wandiga S O, Chem Soc Ethopia., 1991, 5, 49-64.

19. FEPA (Federal Environmental Protection Agency) (1991) National Guidelines and Standards for Industrial Effluents and Water Quality Tests FEPA (Nigeria) Official Gazette, Nigeria, 1991.

20. WHO (World Health Organization) Revision of the WHO Guidelines for Water Quality Report of the First Review Group Meeting on Inorganics, (Netherlands) World Health Organization Geneva WHO/PEP/91.18, 1991.

21. Adeniyi A A, Yusuf K A and Okedeyi O O, Environ Monit Assess., 2008, 137, 451-458.

22. Van der watt H V H, Summer M E and Cabrera M L, J Environ Qual., 1994, 23, 43-49. 


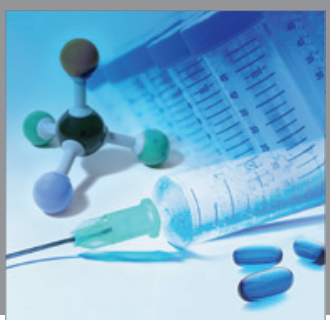

International Journal of

Medicinal Chemistry

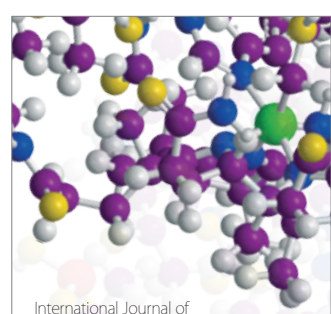

Carbohydrate Chemistry

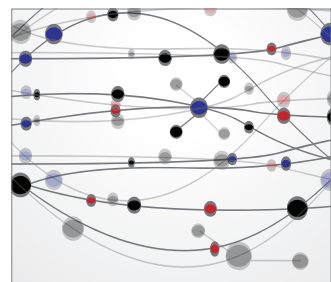

The Scientific World Journal
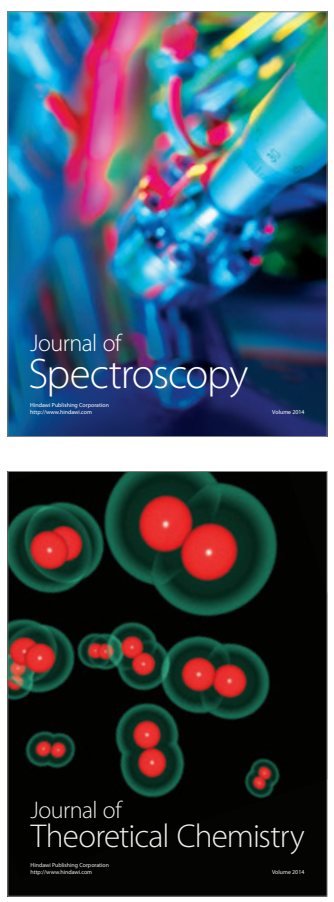
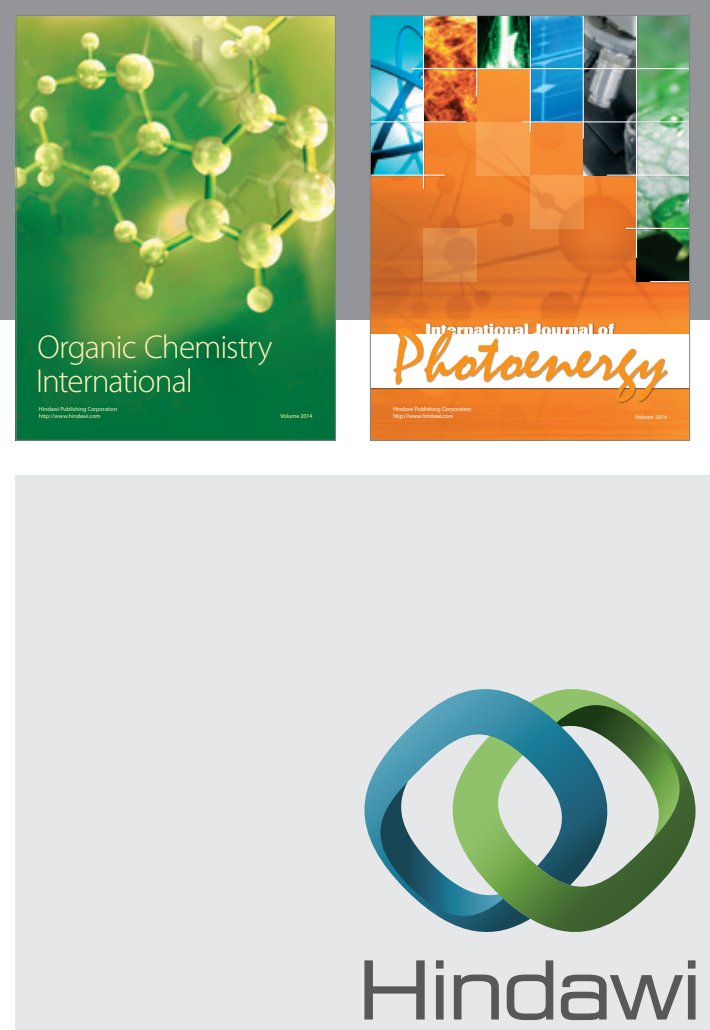

Submit your manuscripts at

http://www.hindawi.com
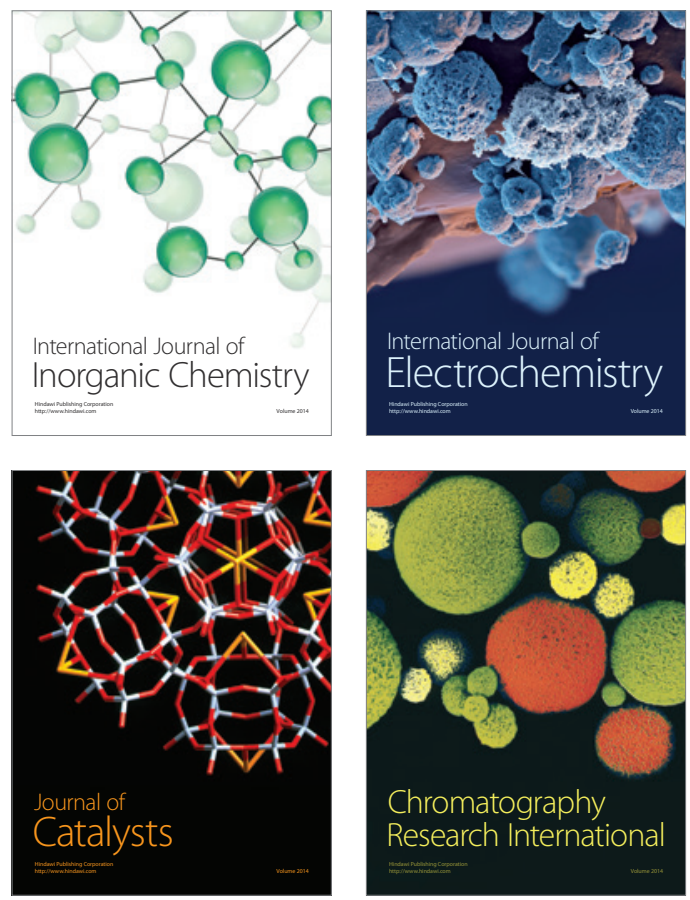
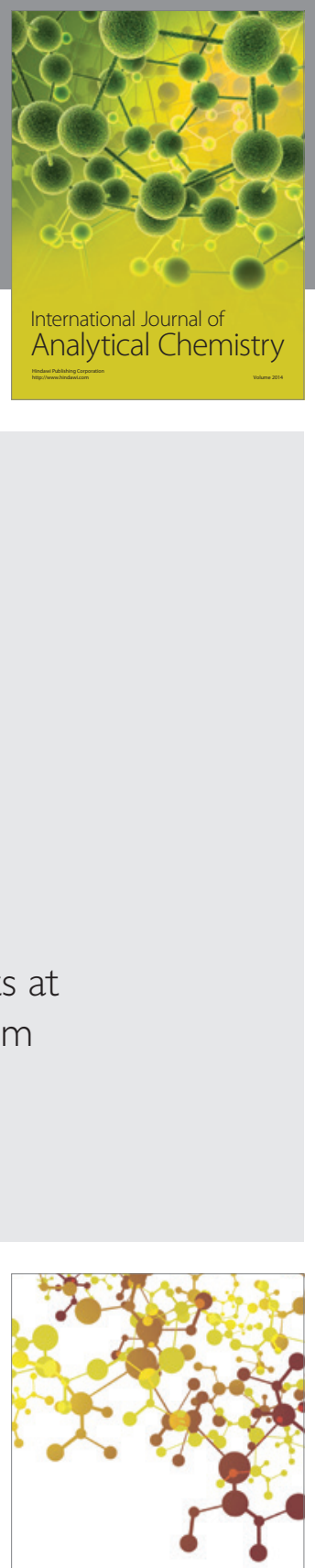

Journal of

Applied Chemistry
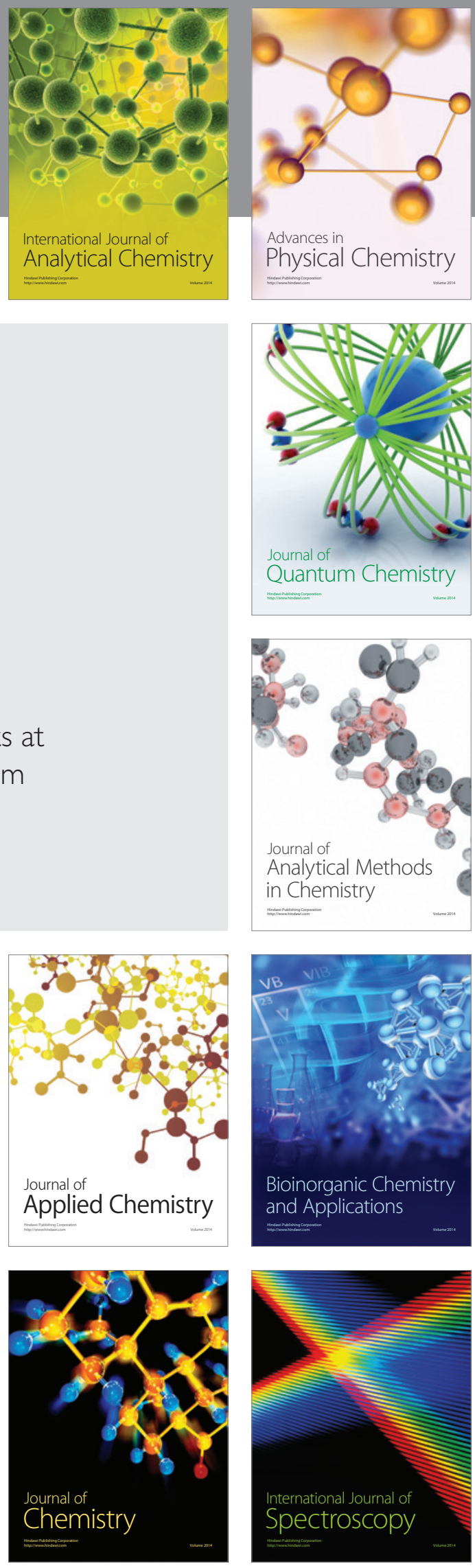